\title{
Abdominal Pain due to Primary Malignant Melanoma of the Small Intestine \\ ${ }^{1}$ Tuncer Temel, ${ }^{2}$ Pınar Yıldız, ${ }^{1}$ Ayşegül Özakyol

\author{
${ }^{1}$ Eskişehir Osmangazi University, Faculty of Medicine, Department of Internal Medicine, Division of \\ Gastroenterology, Eskisehir. \\ ${ }^{2}$ Eskişehir Osmangazi University, Faculty of Medicine, Department of Internal Medicine, Eskisehir. \\ e-posta: ttemel@ogu.edu.tr
}

\begin{abstract}
To describe a patient presented with abdominal pain due to primary malignant melanoma of the small intestine. A 73-yr-old presented with anorexia, weight loss, colicky abdominal pain. Upper GI tract endoscopic and colonoscopic findings were normal. CT scan of the abdomen revealed a solid tumor, possibly originating from the distal jejenal segments as diffuse thickening of the intestinal wall, dilatation of the proximal segments of the intestine and mesenteric lymph node enlargement. Exploration laparotomy revealed a solid tumor, causing invagination, $4 \times 3 \mathrm{~cm}$. in size, approximately $60 \mathrm{~cm}$. from the treitz. Histopathological examination of the resected specimen made the diagnosis of malignant melanoma. The search for the primary site was negative. After the wide excision of the tumor and mesenteric lymph nodes, six months after the operation the patient remains well. Primary malignant melanoma of the small intestine is a rare condition that surgical intervention give the best chance for effective palliation and disease-free survival.
\end{abstract}

KEY WORDS: Primary malignant melanoma, small intestine.

ÖZET: İnce bağırsağın primer malign melanomu nedeniyle karın ağrısı tanımlayan bir hasta sunuldu.73 yaşında erkek hasta anoreksi, kilo kaybı ve kolik abdominal ağrı ile başvurdu. Üst gastrointestinal endoskopisi ve kolonoskopisi normaldi. Abdomen CT'sinde distal jejenal ans diffüz incelten ve proksimal segmentte dilatasyon yaratan solid kitle görüldü. Eksplorasyon laparatomisinde Treitz ligamanından yaklaşık $60 \mathrm{~cm}$ mesafede $4 \times 3 \mathrm{~cm}$ solid tümöre ulaşıldı. Histopatolojik tanısı malign melanom olarak konuldu. Primer tümör araması negatifti. Tümör ve lenf nodları geniş eksize edildi ve operasyondan 6 ay sonra hasta halen iyiydi. İnce bağırsaklarda primer malign melanom nadir bir durumdur ve efektif palyasyon ve hastalıksız sağ kalım için cerrahi hastaya verilen en iyi şanstır.

ANAHTAR KELIMMELER: Primer malign melanom, ince bağırsak.

Introduction: Malignant melanoma is one of the most common neoplasms. However, primary noncutaneous melanoma is a rare entity and is most often described in ocular, mucosal and leptomeningeal sites ${ }^{1}$. Malignant melanomas constitute approximately \%1$\% 3$ of all malignant tumors of the gastrointestinal tract and metastatic lesions are more common than primary tumors ${ }^{2,3}$. Herein, we report the very unusual case of a primary malignant melanoma of the small bowel in a old patient.

Case: A 73-yr-old woman admitted with 1 month history of colicky abdominal pain, anorexia, weight loss and clinically detoriation for 1 week prior to hospital admission because of vomitting, prominent abdominal distantion and loss of defecation. Physical examination revealed paleness, abdominal distantion and tenderness. Laboratory results were with in the normal range except for a moderate hypochromic-microcytic anemia and prerenal azotemia. Upper GI tract endoscopic and colonoscopic findings were normal. CT scan of the abdomen revealed a solid tumor, possibly originating from the distal jeujenal segments as diffuse thickening of the intestinal wall, dilatation of the proximal segments of the intestine and mesenteric lymph node enlargement. Exploration laparotomy revealed a solid tumor, causing invagination, $4 \times 3 \mathrm{~cm}$. in size, ulcerating-vagetan, approximately $60 \mathrm{~cm}$. 
from the treitz. Enlarged mesenteric lymph nodes were identified. Examination of the abdominal cavity revealed no macroscopic evidence of metastasis. Wide excision of the tumor, mesenteric lymph node disection and an end-to-end anastomosis was performed. Histopathologic examination of the specimen showed a neoplastic lesion; melanocytic cells in the basal layer of the epithelum showing pagetoid extension with marked cytologic atypia with large eosinophilic nucleoli, abundant mitotic figures, melanin containig cytoplasmic granules and positive immunohistochemical staining for S-100 and HMB-45. Histopathologic findings established a diagnosis of malignant melanoma. Clinical and laboratory examination to exclude the presence of primary cutaneous, ocular or a melanoma in any other site was negative. The lesion was determined as primary malignant melanoma of the small intestine. six months after the operation the patient remains well.

Discussion: Small intestine involvement by malignant melanoma is most frequently metastatic and primary origin at this site is presented as case reports. There is no specific symptom related with the primary malignant melanoma of the small intestine and the clinical presentation is smilar to that of other primary tumors of the small intestine; abdominal pain (\%62), hemorrhage (\%50), nausea and vomitting (\%26), mass (\%22), intestinal obstruction (\%18). Primary intestinal melanoma seems to be associated with a worse prognosis and a more aggressive behaviour due to rapidly growth for a rich vascular and lymphatic supply of the intestinal mucosa respect to metastatic one $e^{4}$. Although the small and large intestines normally contain no melanocytes, these cells have been occasionally found in the alimentary and respiratory tracts and even in lymph nodes ${ }^{5}$ Melanomas of the small bowel are thought to originate from melanoblastic cells of the neural crest, which migrate to the distal ileum through the umbilical mesenteric canal. Blecker et al. propose the following criteria for a diagnosis of primary melanoma of small bowel: presence of a solitary mucosal lesion in the intestinal epithelium, absence of melanoma or atypical melanocytic lesions of the skin and presence of intramucosal melanocytic lesions in the overlying or adjacent intestinal epithelium ${ }^{3}$. Primary malign melanoma of the intestinal tract are the absence of a previous or synchronously melanom and the absence of metastatic spread to other organs ${ }^{6}$.

Diagnostic tools are endoscopic evaluation, unreliable CT scanning with estimated sensitivity approximately \% 6070 , an unreliable diagnostic tool, enteroclysis, can be used either ${ }^{7}$. Surgical resection with wide margins is the treatment of choice. Chemotheropeutic agents including interferon $\alpha$, cytokines, biological agents and radiation therapy for brain metastases are adjuvant and palliative therapies for malignant melanoma ${ }^{8}$.

Prognosis depends on the excistance of metastases at the time of diagnosis and the primary malignant melanoma subset; younger patients, aggressive disease with rapid metastases and very poor prognosis; older patients indolent disease with less rapid metastases ${ }^{9}$. Early stages, primary malignant melanoma are usually asymptomatic and diagnosis is delayed. The occurence of potantially life threatening complication are such as intestinal intussusception, obstruction, bleeding or perforation which is presented in different cases ${ }^{10,11}$.

In conclusion; primary malignant melanoma of the small intestine is a rare neoplastic lesion of the gut that appropriate diagnosis can only made after exculusion of a coexisting primary lession elsewhere, metastatic spread to other organs, presence of intramucosal lesion of the overlying or adjacent intestinal mucosa. 


\section{REFERENCES}

1. Chang, A.E. Karnell, L.H. Menck, H.R. (1998). The National Cancer Data Base report on cutaneous and noncutaneous melanoma: a summary of 84,836 cases from the past decade. The American College of Surgeons Commission on Cancer and the American Cancer Society. Cancer. 83:1664-1678.

2. Sachs, D.L. Lowe, L. Chang, A.E. Carson, E. Johnson, T.M. (1999). Do primary small intestinal melanomas exist? Report of a case. J Am Acad Dermatol. 41:1042-1044.

3. Blecker, D. Abraham, S. Furth, E.E. Kochman, M.L. (1999). Melanoma in the Gastrointestinal Tract. Am J Gastroenterol. 94:3427-3433.

4. Kim, W. Baek, J.M. Suh, Y.J. Kim, J.A. Jeon, M. (2004). Ileal Malignant Melanoma Presenting as a Mass with Aneurysmal Dilatation: A case report. J Korean Med Sci. 19:297-301.

5. Woodruff, J.M. (1976). Pathology of malignant melanoma, Part I. Clin Bull, 6:15-23

6. Ridolfi, R.L. Rosen, P.P. Thaler, H. (1977). Nevus cell aggregates associated with lymph nodes. Cancer, 39:164-171.
7. Konstantinos, S.A. Theodore, E.P. Basilios, T.P. Thomas, B.P. (2002). Primary Malignant Melanoma of the Small Intestine: Report of a Case. Surg Today.32:831-833.

8. Schuchter, L.M. Green, R. Fraker, D. (2000). Primary and Metastatic Diseases in Malignant Melanoma of the Gastrointestinal Tract Currr Opin Oncol.12(2):181-185.

9. Mandot, A. Kaz1, K. Gupta, T. Desai, D. Abraham, P. Joshi, A. (2006). Primary Malignant Melanoma of Right Colon. Indian J Gastroenterol. 25:96-97.

10. Elsayed, A.M. Albahra, M. Nzeako, U.C. Sobin, L.H. (1996). Malignat Melanomas in the Small Intestine:a study of 103 patients. Am J Gastroenterol. 91:1001-1006.

11. Atmatzidis, K.S. Pavlidis, T.E. Papaziogas, B.T. Papaziogas, T.B. (2002). Primary malignant melanoma of the small intestine: report of a case. Surg Today. 32:831-833.

12. Li, W.X. Wei, Y. Jiang, Y. Liu, Y.L. Ren, L. (2014). Primary colonic melanoma presenting as ileocecal intussusception: case report and literature review. World $J$ Gastroenterol. 28;20(28):9626-9630. 